\title{
A framework to facilitate institutional arrangements for smallholder supply in developing countries: An agribusiness perspective
}

\author{
Kurt Sartorius , Johann Kirsten
}

\section{Introduction}

The industrialization of agriculture in many developed countries has resulted in the tighter alignment of supply chains and promoted the emergence of fewer larger farms. It has been suggested that this trend could exclude small-scale farmers in developing countries from profitable niche markets. In this respect, it is also argued that smaller operations, not linked with agribusiness, will have increasing difficulty in gaining the economies of size and the access to technology that is required in order to be competitive (Kandiwa, 1999; Boehlje and Doering, 2000; Reardon and Barrett, 2000; Stanton, 2000; Unneveher, 2000). Furthermore, it is often problematic for agribusiness to ignore larger suppliers and include small-scale farmers in high risk supply chains because of the incremental transaction cost (Runsten and Key, 1996; Rehber, 1998; Key and Runsten, 1999; Kirsten and Sartorius, 2002).

This reality, combined with the search for appropriate policy options for pro-poor agricultural growth, provides a major challenge in many developing countries. The objective of the paper is to contribute to a better understanding of the variables that influence the preferred choice of smallholder-agribusiness contracting arrangements in a developing country context. More specifically, this paper will demonstrate how trust and other conditions can influence the structure and cost of smallholder contracting supply arrangements. The principal research question is whether an investment in trust in a smallholder-agribusiness raw commodity supply arrangement can significantly influence the choice of the most suitable contract arrangement in high risk conditions. This paper argues that agribusiness firms in developing countries can make a major contribution in assisting smallholders to overcome the barriers of entry to the commercial farm sector. Our paper, which takes an agribusiness perspective of the problem, provides a complimentary approach to the policy options and institutional arrangements for pro-poor growth suggested by Dorward et al. (2004). In addition, it contributes a further perspective to the operationalization of transaction cost economics that is complimentary to the approach of Williamson (2000).

The importance of looking for ways to successfully include smallholders in the agribusiness supply chains of developing countries is underlined by the high rate of failure of small-scale farmer contracting projects in these countries (Watts, 1994; Little, 1994; Glover, 1994; Von Braun and Kennedy, 1994; Runsten and Key, 1996; Delgado, 1999). In this regard, the problem of smallholder exclusion is especially problematic in Southern Africa where historical legacies have contributed to the exclusion of small-scale black farmers in the commercial farm sector (Bundy, 1979; Kirsten and van Zyl, 1996; Mbonga et al., 1990; Machethe et al., 1997; Van Zyl and Kirsten, 1999).

The study uses a case study methodology to test the principal research question because of the qualitative nature of the data, as well as the opportunity to explore a wider range of 
variables that influence the success of smallholder contracting arrangements with an agribusiness partner. A case study in the sugarcane and timber sectors was specifically selected because both of these industries have a long history in Southern Africa of engaging with smallscale suppliers.

An outline of the remainder of the study is as follows: Section "A transaction cost framework" develops a transaction cost framework that can be applied to the analysis of the case study. Section "The transaction cost of supply: a case study in the Southern African sugar and timber industries" introduces a case study in the sugar and timber industries of Southern Africa. Section "Does the level of trust significantly influence the choice of contract structure?', tests the principal research question. Section "Institutional arrangements and policy to reduce transaction cost" suggests some institutional arrangements and finally, Section "Summary and conclusion" outlines a summary and conclusion and the direction of future research.

\section{A transaction cost framework}

The objective of this section is to design a framework that can be used by an agribusiness processor to select an appropriate governance form for a given set of supply contract characteristics. In this regard, processor transaction costs are first discussed before a transaction cost framework is constructed.

\section{Processor transaction costs}

The costs of exchange for the processor include the bureaucratic costs of maintaining a purchasing office, the costs of searching for suppliers, the costs of establishing a contractual relationship and the value and time to communicate and co-ordinate all the supplying farmers. In particular, modern supply chains rely on the consistent supply of high volumes of homogeneous quality raw commodities whose delivery is carefully synchronized with the processing operations and transaction cost is incurred as a result of the need to administer, inspect and monitor deliveries (Sporleder, 1992; King, 1992; Featherstone and Sherrick, 1992; Frank and Henderson, 1992; Rhodes, 1993; Glover, 1994; Pasour, 1998; Rehber, 1998; Stanton, 2000; Hayes et al., 2000).

\section{The selection of a governance structure}

Various frameworks to test the risk and suitability of governance structures have been examined in a number of agricultural settings for a wide range of raw commodities (Minot, 1986; Jaffee, 1995; Delgado, 1999; Dorward, 1999). A further contribution by Sartorius and Kirsten (2005), developed a framework to objectively quantify the contract characteristics of an exchange relationship in order to match these with an appropriate governance structure. Using a similar framework the same approach is extended to test whether trust significantly influences the choice of governance structures in high risk contract characteristics of exchange. Firstly, the framework is based on a set of 10 contract characteristics in a supply relationship. These characteristics, illustrated in Table 1, include the frequency of supply, the level of asset specificity and the degree of uncertainty. In this regard, seven contract characteristics and the agro-ecological conditions of supply are used as proxies to measure the level of uncertainty. Contract characteristics influencing the uncertainty of a given set of contract conditions include whether the exchange partners can walk away from the contract (the switching cost), whether or not there are substitutes available, the duration of the contract and the degree to which all the contractual conditions and costs can be specified up front (ex ante control).

Other contract characteristics include the degree to which actual conditions can only be managed during the course of the contract (ex post importance), the amount of information that needs to be shared and how contract enforcement is managed. In an agricultural supply 
context, however, uncertainty is also influenced by a range of agro-ecological variables that includes climate, disease and heterogeneity of quality. Each of the 10 contract characteristics, namely, frequency, asset specificity and uncertainty are graded in terms of five levels of intensity that are matched with one of the five governance structures within the vertical coordination (VC) continuum. The framework, therefore, matches 10 contract characteristics with five governance forms. In this regard, Peterson and Wysocki $(1997,1998)$ propose that any economic activity can be organized by a continuum of

Table 1

The transaction cost framework

Contract characteristics VC continuum

\begin{tabular}{|c|c|c|c|c|c|}
\hline & Grade 1 & Grade 2 & Grade 3 & Grade 4 & Grade 5 \\
\hline & $\begin{array}{l}\text { Classical } \\
\text { contracting } \\
\text { Spot market }\end{array}$ & $\begin{array}{l}\text { Neo classical } \\
\text { contracting } \\
\text { Specification } \\
\text { contracting }\end{array}$ & $\begin{array}{l}\text { Neo classical } \\
\text { contracting } \\
\text { Strategic } \\
\text { alliance }\end{array}$ & $\begin{array}{l}\text { Bilateral } \\
\text { relational } \\
\text { Formal co- } \\
\text { operation }\end{array}$ & $\begin{array}{l}\text { Unified } \\
\text { relational } \\
\qquad \\
\text { Full vertical } \\
\text { integration }\end{array}$ \\
\hline Frequency & Low & Low-medium & Medium & High & Very high \\
\hline $\begin{array}{l}\text { Asset specificity } \\
\text { Uncertainty } \\
\text { Ability to walk away/ } \\
\text { Switching cost }\end{array}$ & $\begin{array}{l}\text { Low } \\
\text { Yes/low }\end{array}$ & $\begin{array}{l}\text { Low-medium } \\
\text { Yes/lower }\end{array}$ & $\begin{array}{l}\text { Medium } \\
\text { Less }\end{array}$ & $\begin{array}{l}\text { High } \\
\text { Low/higher }\end{array}$ & $\begin{array}{l}\text { Very high } \\
\text { No/high }\end{array}$ \\
\hline Substitutes & Yes & Yes/less & Less & No & No \\
\hline Duration & Short & Short/medium & Medium & Long & Very long \\
\hline Ex ante control & High & Lower & Low & No & No \\
\hline Ex post importance & Low & Low/medium & Medium & High & Very high \\
\hline Information shared & Low & Low/medium & Medium & High & Extensive \\
\hline Contract enforcement & Legal & Legal-complex & Complex & Bilateral & Hierarchy \\
\hline Agro-ecological & Low & Low-medium & Medium & Medium-high & High \\
\hline
\end{tabular}

Based on: Sartorius and Kirsten (2005). \# If aggregated TCE score indicates full vertical integration then high levels of trust suggest/promote bilateral relational as a more cost effective alternative. If aggregated TCE score indicates specification contracting then high levels of trust promote this structure to a form of bilateral relational contracting.

governance structures that range between the open market and full vertical integration and that each of these structures can be represented by some form of contracting. Transaction cost theory suggests that, given a low to moderate level of uncertainty, transactions that are both infrequent and that display low levels of asset specificity are best co-ordinated by the market place. The reason for this is that little opportunity exists for opportunism by the buyers and the potential for information asymmetry is low. Conversely, high levels of frequency, asset specificity and uncertainty, are best coordinated by a fully vertically integrated governance form because the possibility of opportunism and information asymmetry is much higher. Other governance forms on the vertical coordination continuum include specification contracting, a strategic alliance and formal co-operation. In this regard, specification contracting is suited to a recurrent contracting arrangement in lower risk conditions whilst a strategic alliance or a formal partnership becomes increasingly necessary as the level of uncertainty and asset specificity increases. In the case of open market trading, a specification contract, a strategic alliance and a formal partnership, the contracting parties maintain their separate identities in the contracting arrangement (Williamson, 1975, 1981, 1996).

The framework, illustrated in Table 1, is operationalized as follows. Firstly, the 10 contract characteristics of supply in a hypothetical situation are identified, analyzed and graded. Each of 
the characteristics are then located in the framework by matching the graded characteristic with a suitable governance form. For each entry a score of one is allocated in the appropriate column. The same matching process would be completed for all the 10 contract characteristics in Table 1 and the scores out of 10 (10) in each column (governance structure) aggregated in the summary row. If all 10 contract characteristics are located in the column (Grade 1) marked Spot Market then a score of 10 will be recorded in the summary row of column one. The optimum governance form will suggest a 10/10 weighting for the governance structure marked Open Market. If all 10 contract characteristics are recorded in the column marked full vertical integration then a score of 10 in the summary row will suggest a 10/10 weighting for the governance structure marked Full Vertical Integration. If five characteristics are located in column four (formal partnership) and five in column five (full vertical integration) then the summary scores in the two columns would suggest a structure that ranges between full vertical integration (5/ 10) and a formal partnership (5/10). If the aggregated scores of the columns are more weighted towards the left-hand side of the table then the contract conditions are likely to be more suitable to the open market. Conversely, if the aggregated score is more weighted to the right-hand side of the table then the conditions are better suited to being internally coordinated in the firm's hierarchy.

Transaction cost theory (TCE) proposes that an ongoing supply relationship, between a processor and farmers in a competitive environment, will structure itself, over time, in such a way that the contractual costs of exchange will be minimized for the given level of output and the influence of the prevailing institutional environment (Coase, 1990; Williamson, 1975, 2000). The validity of these assumptions, however, has been questioned from the perspective that TCE oversimplifies/ignores social exchange theory (Demsetz, 1988; Ring and van den Ven, 1992, 1994; Williamson, 2000; Langfield-Smith and Smith, 2003) that includes issues like trust and the evolution of human behaviour in a recurrent contracting situation (Berger et al., 1993; Ring and van den Ven, 1994; Chiles and McMackin, 1996; Pitelis, 1996; LangfieldSmith and Smith, 2003).

\section{Accommodating trust in the conceptual framework}

Trust is one of the most important elements influencing the transaction cost of monitoring and taking protective measures in supply chains in a recurrent contracting situation. Trust reduces opportunistic behaviour thus reducing the need to monitor and control the other party and the need to take precautionary measures. Trust, therefore, facilitates the choice of less costly (detailed) contracts in complex recurrent contracting conditions because the parties mutually manage contract enforcement and they are less likely to exploit information asymmetry situations (Bryant and Colledge, 2002; Langfield-Smith and Smith, 2003; Handfield and Bechtel, 2004; Moore and de Bruin, 2004). It can, therefore, be hypothesized that in high risk conditions transaction cost theory may select a preferred governance form that ignores the impact of trust. In this regard, Ring and van den Ven $(1992,1994)$ propose that in the presence or absence of trust, TCE can predict the wrong governance form. For example, they claim bilateral relational contracting (partnerships) is the most suitable governance form to coordinate high risk repeated exchange conditions involving partners who trust each other. The reason for the choice of a bilateral relational structure is explained by the parties being able to adopt a more flexible approach to ex post developments and the adoption of precautionary and control measures. TCE, on the other hand, would propose the use of full vertical integration to coordinate the same exchange characteristics. In this regard, Ring and van den Ven (1992) propose that TCE ignores the crucial role that informal, socially embedded relationships have in producing stable contract conditions between independent parties. They also propose that the bureaucracy costs of the firm are greater than the more flexible bilateral 
relational contracting conditions that are made possible because of the presence of trust. In Table 1 the impact of trust in high risk conditions would be reflected by a shift away (left) from the column marked full vertical integration to the column marked bilateral relational contracting indicating the suitability of a lower level of managed control. Conversely, a lack of trust in high risk bilateral contracting conditions would suggest a move (right) to full vertical integration because this structure reduces the cost of coordinating the multiple legal arrangements (Glover, 1984; Levin, 1988; Currie and Ray, 1986; Mahoney, 1992; Porter and Phillips-Howard, 1997a,b; Fafchamps and Minten, 1999; Delgado, 1999; Tre-gurtha and Vink, 1999).

\section{The transaction cost of supply: a case study in the Southern African sugar and timber industries}

The transaction characteristics of supply are discussed in a case study setting in the sugar and timber sectors of Southern Africa. Firstly, the processor companies and their raw commodity suppliers are introduced before discussing the transaction (contract) characteristics of supply and the issue of trust.

\section{The companies}

The case study incorporates two sugar producers and a producer of dissolved pulp. The sugar companies are the Mhlume Sugar Company (MSCo) in Swaziland and the Transvaal Sugar company (TSB) in the Mpumalanga Province of South Africa. The producer of dissolved pulp is the Sappi-Saiccor Company in the Kwazulu-Natal Province of South Africa. In all three instances, the supply of the principal raw commodity, illustrated in Table 2, is procured from a number of sources including own company estates and a range of both large, medium and small-scale contracted growers whose activities are coordinated by some form of long term specification contract. TSB and Sappi-Saiccor employed a formal detailed long term specification contract to coordinate smallholder supply. Conversely, Mhlume Sugar used a more informal specification supply arrangement that is renewed annually. In the case of the sugar study, the small-scale farmers have been coordinated by their own farmers associations for between 15 and 30 years whilst in the case of the timber study, a rural management organization, contracted by the company, has managed their affairs for the last 15 years.

Table 2

Production of raw commodities

\begin{tabular}{lcrrrrr}
\hline Growers & \multicolumn{2}{c}{ MSCo } & & TSB & \multicolumn{2}{c}{ Sappi } \\
\cline { 2 - 6 } & Area Ha & \% & Area Ha & Area & Area & \% \\
\hline Company estate & 8791 & 67 & 7932 & 18 & 500000 & 90 \\
Contract small & 2329 & 18 & 7473 & 18 & 4223 & 1 \\
Contract medium /large & 2042 & 15 & 27605 & 64 & 50000 & 9 \\
Total & 13162 & 100 & 43010 & 100 & 554223 & 100 \\
\hline
\end{tabular}

The contract characteristics of raw commodity supply

The classification and grading (1-5) of the raw commodity supply contract characteristics in Table 3 has been developed for all three supply chains. The delivery and processing of large volumes of perishable commodities, like sugarcane and timber, requires complex co-ordination of the activities of the growers with the optimum use of high fixed cost processing facilities. The contract characteristics of frequency for both raw commodities were based on the annual number of deliveries to mill. This characteristic was graded as very high (Grade 5) because 
52300 and 136000 deliveries of sugarcane and 46669 deliveries of timber occur per annum. The level of asset specificity was also graded as very high (Grade 5) because of the high cost of the dedicated plant and equipment in all three operations (R2-R5 billions), because the assets have a low disposable value, because these assets cannot be used in another location and because high levels of synchronization are required to coordinate their use.

A summary of the other contract conditions influencing uncertainty indicate a moderate to high level of uncertainty because of the switching costs or the limited ability to walk away from the contract (Grades 3-4), the fact that there are no substitutes (Grade 5), the duration of the arrangement is 10 years or more (Grades 3-4), there is a low level of ex ante control in the supply arrangements (Grade 5), a high level of ex post importance (Grade 5) in the supply conditions and a medium to high level of information (Grades 3-4) shared between the processor and the growers. Contract enforcement is complex and relies on mutual interest rather than the courts (Grade 3). Finally, the climate has a limited impact on sugarcane which is grown under irrigation whilst timber growers are mostly located in high rainfall regions. In both instances, growers have access to company

Table 3

Supply chain contract characteristics

\begin{tabular}{|c|c|c|c|}
\hline \multirow[t]{2}{*}{ Contract characteristics } & Sugar & Sugar & Timber \\
\hline & $\begin{array}{l}\text { Mhlume } \\
\text { Company }\end{array}$ & $\begin{array}{l}\text { Transvaal sugar } \\
\text { Company }\end{array}$ & $\begin{array}{l}\text { Sappi-Saiccor } \\
\text { company }\end{array}$ \\
\hline Risk assessment & High & High & High \\
\hline Trust construct: company & Medium-high & Medium-high & Low \\
\hline Trust construct: farmers & Medium-low & Medium-low & Low \\
\hline 1. Frequency: deliveries per year & 5 (Very high) & 5 (Very high) & 5 (Very high) \\
\hline $\begin{array}{l}\text { 2. Asset specificity: value of processors plant } \\
\text { and equipment }\end{array}$ & 5 (Very high) & 5 (Very high) & 5 (Very high) \\
\hline \multicolumn{4}{|l|}{ 3. Uncertainty } \\
\hline $\begin{array}{l}\text { Ability to walk away from contract/ } \\
\text { switching cost }\end{array}$ & $\begin{array}{l}3 \text { (Limited/ } \\
\text { high) }\end{array}$ & 3 (Limited/high) & 4 (Limited/high) \\
\hline Substitutes & 5 (None) & 5 (None) & 5 (None) \\
\hline Duration & 3 (Long) & 3 (Long) & 4 (Long) \\
\hline Ex ante controls & 5 (No) & $5(\mathrm{No})$ & $5(\mathrm{No})$ \\
\hline Level of ex post importance & 5 (High) & 5 (High) & 5 (High) \\
\hline Information shared & $\begin{array}{l}3 \\
\text { (Considerable) }\end{array}$ & 3 (Considerable) & 4 (High) \\
\hline Contract enforcement & 3 (Complex) & 3 (Complex) & 4 (Complex) \\
\hline Agro-ecological & $\begin{array}{l}2 \text { (Low- } \\
\text { medium) }\end{array}$ & 2 (Low-medium) & 2 (Low-medium) \\
\hline Summary score & Grade 4 & Grade 4 & Grades 4-5 \\
\hline
\end{tabular}

technicians with respect to the control of disease or other technical problems that could influence quality or increase the risk of supply (Grade 2). A summary of the raw commodity supply characteristics for all three companies, combined with political, industry and macroeconomic instabilities, suggests high levels of risk exacerbated by very high levels of frequency and asset specificity and a moderate to high level of uncertainty.

\section{Trust in the supply chains}

In a study by Masuku (2003) and Sartorius et al. (2003), the level of smallholder trust in the Swaziland sugar supply chain was examined by two constructs. In the first, the results indicated that $80 \%$ of farmers were satisfied with the relationship of whom $66 \%$ trusted the miller and 34\% did not. Furthermore, $73 \%$ of all farmers felt that the miller demonstrated 
opportunistic behaviour and $82 \%$ indicated undue influence by the miller. In addition, $72 \%$ of respondents felt there was no co-operation and 69\% felt dependent on the miller. Conversely, 98\% felt there was commitment by the company. The overall (somewhat conflicting) results indicate a marginal level of trust that is promoted by mutual interest, the reliability of the mill and a perception that the mill is concerned about their welfare.

An assessment of trust by the small-scale farmer department in the TSB also indicated a marginal level of farmer trust but, in the case of the timber supply chain, the company officials indicated that lower levels of trust were evident in both the farmers and the company. From a company perspective in both the MSCO and TSB supply chains, smallholders supply significant volumes of sugarcane (20\%) and their farmer associations are represented in the processing decisions of the mill. Both companies, moreover, have invested large sums of money in training, in the provision of services and in local community structures and provide considerable inputs with respect to the management of their small-scale growers' financial affairs. Furthermore, both companies have significantly expanded smallholder supply in the last 10 years. If it can be assumed these company investments in smallholder farming can be treated as proxies for trust, then it can also be assumed that fairly high levels of company trust exist with respect to smallholder supply. In Table 3 above, therefore, trust in the two sugar studies has been graded as medium to high from a company perspective and medium to low from a farmer perspective.

In the case of Sappi-Saiccor, the smallholder timber supply arrangement began as a 'window dressing' exercise and has been far less successful. The arrangement, secured by a very detailed long term specification contract, has only been in operation over the last fifteen years and has proved to be costly. Company officials maintain that the arrangement has only lasted because of the high level of administrative input provided by the company who manages the farmers through a contracted organization. Much lower levels of trust appear to exist despite similar levels of inputs and investments in the local community as the sugar study. In Table 3, therefore, trust has been graded as low.

\section{Does the level of trust significantly influence the choice of contract structure?}

The resolution of the research problem begins by plotting the 10 graded actual contract characteristics of sugarcane and timber supply in the framework in order to estimate the most suitable governance form. In Table 4, the summary row indicates the aggregated score out of 10 (10) for the entries in each column. In column two (Specification Contracting), for example, the summary row reflects a score of one (1) for sugar and timber (in bold) because only one contract characteristic has been graded at a level two, namely, the estimated level of agroecological risk. The framework suggests, that in the absence of trust, the 10 contract characteristics for sugarcane are best coordinated by a structure that ranges between a strategic alliance (4/10) and full vertical integration (5/10) because of very high levels of frequency, asset specificity and a moderate level of uncertainty. The framework also suggests that timber supply is best coordinated by a structure that ranges between a formal alliance (4/10) and full vertical integration (5/10) because of very high levels of frequency, asset specificity and a slightly higher level of uncertainty than sugarcane supply. 
Table 4

The impact of trust on the choice of governance form ${ }^{\mathrm{a}}$

\begin{tabular}{|c|c|c|c|c|c|}
\hline \multirow[t]{3}{*}{ Contract characteristics } & \multicolumn{5}{|c|}{ VC continuum } \\
\hline & Grade & Grade 2 & Grade 3 & Grade 4 & Grade 5 \\
\hline & $\begin{array}{l}\text { Spot } \\
\text { market }\end{array}$ & $\begin{array}{l}\text { Specification } \\
\text { contracting }\end{array}$ & $\begin{array}{l}\text { Strategic } \\
\text { alliance }\end{array}$ & $\begin{array}{l}\text { Formal co- } \\
\text { operation }\end{array}$ & $\begin{array}{l}\text { Full vertical } \\
\text { integration }\end{array}$ \\
\hline (a) Frequency & Low & Low-medium & Medium & High & $\begin{array}{l}\text { Very high } \\
\text { sugarcane, timber }\end{array}$ \\
\hline (b) Asset Specificity & Low & Low-medium & Medium & High & $\begin{array}{l}\text { Very high } \\
\text { sugarcane, timber }\end{array}$ \\
\hline \multicolumn{6}{|l|}{ (c) Uncertainty } \\
\hline $\begin{array}{l}\text { Ability to walk } \\
\text { away }\end{array}$ & Yes & Yes/lower & $\begin{array}{l}\text { Less } \\
\text { sugarcane }\end{array}$ & Low timber & No \\
\hline Substitutes & Yes & Yes/less & Less & No & $\begin{array}{l}\text { No sugarcane, } \\
\text { timber }\end{array}$ \\
\hline Duration & Short & Short-medium & $\begin{array}{l}\text { Medium } \\
\text { sugarcane }\end{array}$ & Long timber & Very long \\
\hline Ex ante control & High & Lower & Low & No & $\begin{array}{l}\text { No Sugarcane, } \\
\text { timber }\end{array}$ \\
\hline $\begin{array}{l}\text { Ex post } \\
\text { importance }\end{array}$ & Low & Low-medium & Medium & High & $\begin{array}{l}\text { Very high } \\
\text { Sugarcane, timber }\end{array}$ \\
\hline $\begin{array}{l}\text { Information } \\
\text { shared }\end{array}$ & Low & Low-medium & $\begin{array}{l}\text { Medium } \\
\text { sugarcane }\end{array}$ & High timber & Extensive \\
\hline $\begin{array}{l}\text { Contract } \\
\text { enforcement }\end{array}$ & Legal & Legal-complex & $\begin{array}{l}\text { Complex } \\
\text { sugarcane }\end{array}$ & $\begin{array}{l}\text { Bilateral } \\
\text { timber }\end{array}$ & Hierarchy \\
\hline Agro-ecological & $\begin{array}{l}\text { Low } \\
\text { risk }\end{array}$ & $\begin{array}{l}\text { Low-medium } \\
\text { sugarcane timber }\end{array}$ & Medium & $\begin{array}{l}\text { Medium- } \\
\text { high }\end{array}$ & High risk \\
\hline Summary: sugar 10 & 0 & 1 & 4 & 0 & 5 \\
\hline Score: timber 10 & 0 & 1 & 0 & 4 & 5 \\
\hline $\begin{array}{l}\text { Actual governance } \\
\text { form }\end{array}$ & & Timber sugarcane & & & \\
\hline
\end{tabular}

In this regard, timber supply indicated a need for slightly higher levels of managed control than sugarcane. Furthermore, an assessment of the contract characteristics of both raw commodities suggest that the high risk conditions of supply are exacerbated by fluctuating world prices, as well as regional macro-economic factors. Given these conditions, it would seem that smallholder specification contracting is not a particularly suitable supply arrangement for either raw commodity. This observation is conformed by Langfield-Smith and Smith (2003) who contend that at least a strategic alliance is needed to coordinate the outsourcing of a core/key activity.

Despite these observations, however, the smallholder contracting arrangements in both sugar studies appear to have been successful. In the MSCO supply chain, a renewable informal annual agreement has endured over the last fifteen years and, in the last decade, the volume of smallholder supply has increased whilst farmer associations have become increasingly autonomous. The success of this relationship is evident by the fact that the mill capacity has been expanded to accommodate an additional 6000 hectare of smallholder supply and there is speculation whether or not the company estates will be unbundled to smallholder production. Although the TSB company employs a far more detailed formal long term specification contract, it also has a stable history over the last fifteen years of smallholder supply. The company has invested in the future of smallholder supply and has recently begun unbundling 
some of its estates to smallholder production. In the absence of trust, the stability and success of these two supply chains somewhat contradicts the TCE based assumption that specification contracting is an unsuitable governance form to coordinate sugarcane supply. It can, therefore, be suggested that the moderate levels of trust in both sugar supply chains have played a significant positive role with respect to promoting the success of their specification contracting arrangements with smallholders. Conversely, the lack of trust in the timber case study has merely confirmed the inappropriateness of specification contracting in these conditions.

It can, therefore, be proposed that the presence of trust has modified the contract characteristics of sugarcane supply to the extent that the arrangement has moved from a neoclassical type contract structure to a more relational form of contracting. In Table 4 this would induce a move from left to right as the specification contracting governance form more closely resembles bilateral contracting (formal partnership). Ring and van den Ven (1992, 1994) suggest, that in the presence of trust, contract characteristics of supply in high risk conditions are better managed by bilateral relational contracting where high levels of asset specificity, uncertainty and frequency persist. It could be proposed that trust in the sugar supply chains has improved the suitability of specification contracting as a governance form because it has promoted relational characteristics in the long term supply arrangement. Trust, therefore, has narrowed the gap between the actual governance form and the optimum coordination structure. Conversely, in the timber study the gap between the specification arrangement and higher levels of managed control is not narrowed. Ring and van den Ven $(1992,1994)$ would confirm that, in the absence of trust, the contract characteristics of supply in the timber case study are better managed by full vertical integration. In fact, the failure of its specification contracting arrangement has increasingly resulted in the need for higher levels of managed control by way of company inputs, management and administration in order to coordinate this project. Before coming to a conclusion with respect to whether trust has significantly influenced the suitability of specification contracting, a number of other factors influencing the success of the smallholder contracting arrangements of the three companies need to be questioned.

\section{Other factors influencing the success of the outsourcing Arrangements}

A range of other factors appear to have influenced the relative success of smallholders in the sugar industry and the apparent failure of the timber project. In this regard, Poulton and Lynn (2006) suggest that contract arrangements in a developing country context owe as much to unequal power relationships as to transaction cost minimization. In this regard, unequal power relationships between agribusiness and farmers in South Africa occur because agribusiness is better able to influence the terms of contracts negotiated because of limited alternative opportunities for the farmer, as well as the often poorly organized farmer communities. Furthermore, agribusiness offers limited guarantees to farmers who undertake investments in capacity (Mbonga et al., 1990; Machethe et al., 1997). The case studies in the sugar industry suggest that the companies largely dictated the form of the contract and that the farmers felt the millers exerted undue influence. Countering this was the fact that farmers were well represented by their associations, represented on the company mill committee and by various cane growers associations. Much higher levels of unequal power were apparent in the timber case study where the farmers have no association and are tightly managed by a contracted rural management company (Lima) to the point where they exercise little autonomy. Furthermore, the farmers in the sugar studies suggested they were more satisfied for a range of economic factors than due to high levels of trust. In fact a majority felt their company partner indulged in opportunistic behaviour. In addition, it would be strange to expect especially high levels of farmer trust due to the historical legacies of the two countries (Porter and Phillips-Howard, 
1997a,b). Furthermore, from the company perspective, high levels of smallholder start up cost, administration cost (Sartorius and Kirsten, 2004, 2005) and high levels of asset specificity would tend to make the millers wary of opportunistic behaviour by the contracted smallholders (Berger et al., 1993; Ring and van den Ven, 1992, 1994; Suh and Kwon, 2002). Other factors that question the role of goodwill trust include the fact that farmers see the company as a source of free inputs and their skills (human asset specificity) are locked into the growing of sugarcane. Furthermore, the farmers enjoy reasonable economies of scale as a result by being able to contract out for many overhead costs more effectively than the company estates (Sartorius and Kirsten, 2004). Simultaneously, the smallholder communities in the vicinities of the sugar mills have few alternative opportunities, they are location bound and the perishable nature of the product forces them to deal with the nearest sugar mill. In view of these conditions it can be interpreted that the farmers' decisions to engage with the companies are as much based on perceived outcomes emanating from the relationship than as a result of goodwill trust.

Similarly, from a company perspective, high levels of overhead cost, political pressure, political economy objectives and company strategy to divest out of non-core competencies precipitated the move to outsource to smallholders. In addition, the inability to obtain land or procure higher volumes of supply from commercial farmers, combined with the increasing cost of labour, meant that procurement from smallholders was the only option to increase the volume of processing and optimize the use of capacity. In both cases, moreover, the volume outsourced to smallholders was limited to $20 \%$ of supply thus ensuring risk was reasonably well managed by a portfolio of own production, large farmers and smallholders. It can, therefore, be argued that many other factors, often intertwined with trust, have influenced the success of outsourcing to smallholders in the sugar industry.

Similarly, trust is not the only factor that has contributed to the lack of success of the smallholder timber project. In this instance the relative lack of success of the project cannot be attributed to a lack of trust alone but rather to the unequal power relationship and the remote location of the micro ( 0.6 ha per farm) farmers that require excessive individual coordination costs. In addition, these farmers saw the project as a free hand-out and a majority of their income is earned from other sources. Furthermore, the company appears to have used the project more for political reasons than as a genuine source of supply as this category of farmer accounts for less than $1 \%$ of timber processed.

The results, therefore, do not contradict the conclusion that transaction costs are reduced by the presence of trust (Porter and Phillips-Howard, 1997; Akerlof, 1988; Dietrich, 1996; Gow et al., 2000; Fafchamps and Minten, 1999; Weatherspoon et al., 2001; Tregurtha and Vink, 1999; Dean, 2000) but rather that it is not readily apparent in the case study context whether trust has played a significant role to made smallholder outsourcing more attractive. The results suggest that the significance of trust may have been overstated because of a range of factors that occur in a developing country context. The results also do not contradict the TCE cost minimization assumptions but rather support the later contention of Williamson (2000) that transaction cost is a function of the prevailing institutional environment which in turn is a function of history. Based on these, and other findings of the study and the literature, some recommendations as how to structure smallholder-agribusiness contracting arrangements are appropriate.

\section{Institutional arrangements and policy to reduce transaction cost}

A number of institutional arrangements are suggested in this section that can be employed to better manage and structure the contract characteristics of supply. These include the facilitation of farmers associations and the creation of trust. 


\section{Institutional arrangements}

\section{Farmers' associations}

A farmers' association can influence the contract characteristics of supply as follows: firstly this institution can be used to manage the frequency of interaction by coordinating the logistics and communication of their members, as well as cost effectively deliver inputs that include training, extension and technology acquisition (Little and Watts, 1994; Runsten and Key, 1996; Rehber, 1998). Secondly, mutual asset specificity can be promoted by persuading a farmer association to undertake the acquisition of lumpy capital investments in order to increase the production efficiency of the farmers and raise the exit costs for farmers (Berger et al., 1993; Rehber, 1998; Suh and Kwon, 2002). Finally, a farmers' association can reduce the level of uncertainty by facilitating the ex post conditions in a long term supply contract. In this regard, farmer associations can reduce information asymmetry and opportunism, as well as promote the sharing of information and the facilitation of contract enforcement (Little and Watts, 1994; Runsten and Key, 1996). Moreover, from an agribusiness perspective, it is less risky to form a long term contract with a farmers' association than a series of micro contracts. Farmer associations also have greater power to hold service providers to account, to counter unequal power arrangements, to prevent strategic default, to develop public goods and provide farmers with more 'voice' (Poulton and Lynn, 2006). A further important role for farmers associations is the creation of trust.

\section{The creation of trust}

Farmer distrust, combined with a perceived loss of autonomy and feelings of exploitation (unequal power), has been widely cited as a major cause of contracting failures in developing countries (Glover, 1987; Clapp, 1994; Watts, 1994). On the one hand, the agribusiness partner can facilitate the creation of trust by the use of local interface company officers, by translating important documents into local dialects and small-scale farmer representation in the contract negotiation phase (Porter and Phillips-Howard, 1997a,b; Delgado, 1999). Other agribusiness contract innovations that can improve trust include the facilitation of finance, the administration of growers' affairs and high levels of involvement in local communities (Colchao, 1999; Gow et al., 2000). On the other hand, farmers associations can facilitate the development of trust by ensuring that the farmers are represented with respect to the negotiation of the terms and conditions of supply. In this regard, mutual interest increasingly enforces a wide range of contract conditions better than the courts (Gow et al., 2000). A farmers association can also promote trust by acquiring representation in the agribusiness management structure and ensuring the company, in turn, is represented in its own structure. Finally, trust in an agricultural setting can be promoted by effective communication, continuity, an understanding of each other, common interests and the way problems are resolved (Lang-field-Smith and Smith, 2003; Masuku, 2006).

\section{Summary and conclusion}

The study commenced by debating the issue of smallholder exclusion from agribusiness supply chains before discussing transaction cost in an agribusiness supply chain. A transaction cost framework, incorporating the presence of trust, demonstrated how the transaction characteristics of supply influence the choice of governance structure. A case study was then introduced as a basis to test the research question.

The results suggest that it is difficult to assume that trust has played a significant role in reducing transaction cost in a developing country context because a wide range of other factors contribute to pragmatic stable supply arrangements. The results of the study are useful because they use an expanded transaction cost framework to explain the suitability of a governance 
structure, as well as demonstrate the influence of trust on transaction cost in an agricultural setting. The results are also useful because they investigate an agribusiness, rather than a farmer, perspective of how to structure smallholder arrangements and the study makes some practical institutional proposals to promote smallholder outsourcing. Further research, however, is required in order to accommodate a wider range of commodity diversity and situations, as well as investigating the procurement of raw commodities from different types of contract smallholder like the equity-share schemes proposed by Knight et al. (2003).

\section{References}

Akerlof, G.A., 1988. In: Barney, J.B., Ouchi, W.G. (Eds.), The Market for Lemons: Quality Uncertainty and the Market Mechanism. Jossey-Bass Publishers, San Francisco.

Berger, J., Noordehaven, B., Nooteboom, B., Pennink, B.J., 1993. Understanding the subcontracting relationship: the limitation of transaction cost economics. In: Child, J., Crozier, M., Mayntz, R., et al. (Eds.), Societal Change between Market and Organization. Campus/Westview, Frankfurt, pp. 78-98.

Boehlje, M., Doering, O., 2000. Farm Policy in an industrialized agriculture. Journal of Agribusiness 18 (1), $53-$ 60 (Special issue). Bundy, C., 1979. The Rise and Fall of the South African Peasantry. Heinemann Press, London.

Bryant, A., Colledge, B., 2002. Trust in electric commerce business relationships. Journal of Electronic Commerce 3 (2).

Chiles, T.H., McMackin, J.F., 1996. Integrating variable risk preferences, trust, and transaction cost economics. Academy of Management Review 21 (1), 73.

Clapp, R.A., 1994. The moral economy of the contract. In: Little, Peter D., Watts, Michael J. (Eds.), Living Under Contract. The University of Wisconsin Press.

Coase, R.H., 1990 (1937). In: Coase, R.H. (Ed.), The Firm, the Market and the Law. The Problem of Social Cost (Chapter 5). Abridged in Putterman, L. (Ed.), The Economic Nature of the Firm: A reader.

Colchao, S., 1999. Will AG Banks prosper in age of vertical integration. ABS Banking Journal 91 (11), $26-31$.

Currie, K., Ray, L., 1986. On the class location of contract farmers in the Kenyan economy. Economy and Society 15, 445-475.

Dean, E.B., 2000. Transaction cost economics: from the perspective of competitive advantage. Available from: http://akao.larc.nasa.gov/dfc/tce.htm.

Delgado, C., 1999. Sources of growth in smallholder agriculture in sub-Saharan Africa: the role of vertical integration of smallholders with processors and marketers of high value-added items, vol. 38. Agrekon, pp. 165-189 (Special issue).

Demsetz, H., 1988. The theory of the firm revisited. Journal of Law, Economics, and Organization (1).

Dietrich, M., 1996. In: Groenewegen, J. (Ed.), Opportunism, Learning and Organizational Evolution. Kluwer Academic Publishers, Boston.

Dorward, A., 1999. A risk programming approach for analysing contractual choice in the presence of transaction costs. European Journal of Agricultural Economics 26 (4), 479-492.

Dorward, A., Kydd, J., Morrison, J., Urey, I., 2004. A policy adenda for pro-poor agricultural growth. World Development 21 (1), 73-89.

Fafchamps, M., Minten, B., 1999. Property rights in a flea market economy. MSSD Discussion paper No. 27, International Food Policy Research Institute, Washington, DC.

Featherstone, A.M., Sherrick, B.J., 1992. Financing vertically co-ordinated agricultural firms. American Journal of Agricultural Economics 74 (5), 1232-1237.

Frank, S.D., Henderson, D.R., 1992. Transaction costs as determinants of vertical co-ordination in the US food industries. American Journal of Agricultural Economics 74 (4), 941-950.

Glover, D., 1984. Contract farming and smallholder outgrower schemes in less developed countries. World Development 12 (11), 1143-1157.

Glover, D., 1987. Increasing the benefits to smallholders from contract farming: problems for farmers' organisations and policy makers. World Development 15 (4), 441-448.

Glover, D., 1994. Contract farming and commercialization of agriculture in developing countries. In: Von Braun, E., Kennedy, E. (Eds.), Agricultural Commercialization, Economic Development and Nutrition. The John Hopkins University Press, Baltimore, MD.

Gow, H.R., Streeter, D.H., Swinnen, J.F.M., 2000. How private contract enforcement mechanisms can succeed where public institutions fail: the case of Juhocukor a.s. Agricultural Economics 23, 253-265 (Special issue).

Hayes, D., Hayenga, M., Thompson, S.J., 2000. Transaction Costs Economics and the Evolving Structure of Agricultural Production. IAMA World Food and Agribusiness Congress, Chicago, Illonois.

Handfield, R.B., Bechtel, C., 2004. Trust, power, dependence, and economics: can SCM research borrow 
paradigms? International Journal of Supply Chain Management 1.

Jaffee, S., 1995. In: Jaffee, S., Morton, F. (Eds.), Transaction Costs, Risks, and the Organization of Private Sector Food Commodity Systems, in Marketing Africa’s High Value Foods. Kendall/Hunt Publishing Co.

Kandiwa, V., 1999. Economic performance of smallholder farmers using alternative vertical coordination mechanisms for horticultural crops. MS Thesis, Department of Agricultural Economics, Cornell University.

Key, N., Runsten, D., 1999. Contract farming, small-holders, and Rural Development in Latin America: the organization of agroprocessing firms and the scale of outgrower production. World Development 27 (2), 381401.

King, R.P., 1992. Management and financing of vertical co-ordination in agriculture: an overview. American Journal of Agricultural Economics 74, 1217-1218.

Kirsten, J., Sartorius, K., 2002. Linking agribusiness and small-scale farmers in developing countries: is there a new role for contract farming? Development Southern Africa 17 (4).

Kirsten, J., van Zyl, J., 1996. The contemporary agricultural policy environment: undoing the legacy of the past. Agricultural Land Reform in South Africa. Oxford University Press, Cape Town.

Knight, S., Lyne, M., Roth, M., 2003. Best Institutional Arrangements for Farmworker Equity-share Schemes in South Africa, BASIS CRSP. Department of Agricultural and Applied Economics, University of Wisconsinn, Madison.

Langfield-Smith, K., Smith, D., 2003. Management control systems and trust in outsourcing relationships. Management Accounting Research 14, 281-307.

Levin, R., 1988. Contract Farming in Swaziland: Peasant differentiation and the constraints of land tenure. African Studies 47 (2), 101-120.

Little, P.D., 1994. Contract farming and the development question. In: Little, P.D., Watts, M.J. (Eds.), Living Under Contract. University of Wisconsin Press, Madison.

Little, P.D., Watts, M.J., 1994. Living Under Contract. University of Wisconsin Press, Madison.

Machethe, C., Reardon, T., Mead, D.C., 1997. Promoting farm/non-farm linkages for employment of the poor in South Africa: a research agenda focused on small-scale farms and agro-industry. Development Southern Africa 14 (3).

Mahoney, J.T., 1992. The choice of organizational form: vertical financial ownership versus other methods of vertical integration. Strategic Management Journal 13, 559-584.

Masuku, M. 2003. The role of contractual relationships in the performance of supply chains: The case of the sugar industry in Swaziland, Unpublished PhD Thesis, University of Pretoria.

Masuku, M. 2006. The role of trust in contract enforcement: An analysis of smallholder farmers and sugar millers in Swaziland. Unpublished Study.

Mbonga, M., van den Brink, R., van Zyl, J., 1990. Evolution of the agrarian structure in South Africa. Agricultural Land Reform in South Africa. Oxford University Press, Cape Town.

Minot, N., 1986. Contract Farming and Its Impact on Small Farmers in Less Developed Countries. Working Paper, Michigan State University.

Moore, C., de Bruin, A., 2004. A transaction cost approach to understanding ethical behaviour. A paper presented at the World Congress of Social Economics, Alberville, France.

Pasour, E.C. 1998. The potential impact of increased vertical integration on North Carolina grain farmers North Carolina State University. Available from: http://www.ncsoy.org/pasour2.htm.

Peterson, H.C., Wysocki, A., 1997. The vertical coordination continuum and the determinants of firm-level coordination strategy. Staff Paper 97-64, Michigan State University.

Peterson, H.C., Wysocki, A., 1998. Strategic choice along the vertical co-ordination continuum. Staff Paper 98-16, Michigan State University, East Lansing, Michigan 48824.

Pitelis, C., 1996. In: Groenewegen, J. (Ed.), Seven Reasons Why “'Beyond” Transaction Cost Economics in Thermoeconomics. Kluwar Academic Publishers, Boston.

Porter, G., Phillips-Howard, K., 1997a. Contract farming in South Africa: a case study from Kwazulu-Natal. Geography: Journal of the Geographical Association 82 (354), 1-38.

Porter, G., Phillips-Howard, K., 1997b. Comparing contracts: an evaluation of contract farming schemes in Africa. World Development 25, 227-238.

Poulton, C., Lynn, M., 2006. Coordination for market development. Unpublished Study.

Reardon, T., Barrett, C.B., 2000. Agroindustrialization, globalization, and international development: An overview of issues, patterns, and determinants. Agricultural Economics 23, 195-205 (Special issue).

Rehber, E., 1998. Vertical integration in agriculture and contract farming. Regional Research Project NE-165: Private Strategies, Public Policies, and Food System Performance, University of Massachusetts, Department of Resource Economics, Amherst, MA 01003.

Rhodes, V.J., 1993. Industrialization of agriculture: discussion. American Journal of Agricultural Economics 75 
(5), 1137-1140.

Ring, P., van den Ven, A., 1992. Structuring cooperative relationships between organizations. Strategic Management Journal 13, 483-498.

Ring, P., van den Ven, A., 1994. Developmental processes of cooperative interorganizational relationships. Academy of Management Journal 19 (1), 90-118.

Runsten, D., Key, N., 1996. Contract farming in developing countries: theoretical aspects and analysis of some Mexican cases. Research Report No. 3, August 1996. Report prepared for the United Nations Economic Commission for Latin America and the Caribbean, Santiago, Chile.

Sartorius, K., Kirsten, J.F., Masuku, M., 2003. A new institutional analysis of small-scale farmer contracts and relations in the sugar supply chains of South Africa and Swaziland. In: Proceedings of IAMA Symposium, 21-24 June, Cancun, Mexico.

Sartorius, K., Kirsten, J.F., 2004. The cost efficiency of small farm inclusion in agribusiness supply chains. The South African Journal of Accountancy Research 18 (1), 1-13.

Sartorius, K., Kirsten, J.F., 2005. The boundaries of the firm: why do sugar producers outsource sugarcane production? Management Accounting Research 17.

Sporleder, T.L., 1992. Managerial economics of vertically coordinated firms. American Journal of Agricultural Economics 74, 1226-1230.

Stanton, J.V., 2000. The role of agribusiness development: replacing the diminished role of the government in raising rural incomes. Journal of Agribusiness 18 (2), 173-187, Spring.

Suh, T., Kwon, I.W., 2002. The role of bilateral asset specificity and replaceability on trust in supply chain partner. Working Paper, Boeing Institute of International Business, Saint Louis Universit.

Tregurtha, N.L., Vink, N., 1999. Trust and supply chain relationships: a South African case study. Agrekon 38 (4), 755-765.

Unneveher, L.J., 2000. Food safety issues and fresh food product exports from LDCs. Agricultural Economics 23 (September), 231-240.

Van Zyl, J., Kirsten, J., 1999. Approaches and progress with land reform in South Africa. Agrekon 38 (MayJune), 326-342.

Von Braun, J., Kennedy, E., 1994. Agricultural Commercialisation, Economic Development and Nutrition. John Hopkins University Press, London. Watts, M.J., 1994. Life under contract; contract farming, agrarian restructuring, and flexible accumulation. In: Little, Peter D., Watts, Michael J. (Eds.), Living Under Contract. The University of Wisconsin Press, Madison.

Weatherspoon, D., Cacho, J., Christy, R., 2001. Linking globalization, economic growth an poverty: impacts of agribusiness strategies on sub-Saharan Africa. American Journal of Agricultural Economics 83 (3), 722-729.

Williamson, O.E., 1975. Markets and Hierarchies. Free Press, New York.

Williamson, O.E., 1981. The economics of organization: the transaction cost approach. American Journal of Sociology 87, 548-577.

Williamson, O.E., 1996. In: Groenewegen, J. (Ed.), Efficiency, Power, Authority and Economic Organization. Kluwer Academic Publishers, Boston.

Williamson, O.E., 2000. The new institutional economics: taking stock, looking ahead. Journal of Economic Literature XXXVII (September), 595-613. 